堆積学研 究, 58号, 65-83, 2004

J.Sed.Soc.Japan, No. 58，65-83，2004

\title{
Sedimentation and Holocene evolution of wave-dominated, macrotidal-flat depositional system in the southwestern open coasts of Korean Peninsula
}

\author{
Seung-Soo Chun* and Byong-Cheon Yang*†
}

\begin{abstract}
Sedimentation in the open-coast tidal flats of southwestern Korea is controlled by the combination of wave and tide with seasonal variation. Environmental oscillation takes place between tide-dominated muddy deposition in summer and wave-dominated sandy deposition in winter. Winter storm is a major factor in sedimentation and preservation in the intertidal zone, producing extensive wave-generated parallel lamination and short-wavelength HCS/SCS. Winter storm waves dominate sedimentation over the long term in this setting, resulting in predominant preservation of amalgamated storm beds which are very similar to those associated with shoreface. It causes much confusion in differentiation between deposits in true shoreface and open-coast tidal flat, suggesting that some ancient shoreface deposits should be reinterpreted in terms of the concept of open-coast tidal-flat sedimentation.

The retrograding, coarsening-upward, late Holocene succession in this open coast has resulted from low sedimentation rates under low to moderate rates of sea-level rise. It shows a reverse pattern as compared with the models developed in embayed tidal flats with high sedimentation rate such as Jade- and Fundy-bay tidal flats which show a prograding, fining-upward succession. This result suggests that most southwestern open coasts in Korean Peninsula would have much higher potential to experience coastal erosion and inundation with the future sea-level rise than the coasts developed under high sediment supply.
\end{abstract}

Key words : Holocene transgression, hummocky cross stratification, open coast tidal flat, sea level change, seasonal model of sediment, southwestern coast of Korea, surface sediment distribution

\section{Introduction}

Most works in the tidal-flat sedimentology have focused on the estuarine- and embaymenttype environments during the past few decades, although the coastal classification schemes of Hayes (1979) and Boyd et al. (1992) indicate the abundant existence of the transitional setting

Received : February 6, 2004

* Faculty of Earth Systems and Environmental Sciences, Chonnam National University, Kwangju 500757, South Korea

$\dagger$ Present address : Department of Geological Sciences and Geological Engineering, Queen's University, Kingston, Ontario, K7L 3N6, Canada between wave- and tide-dominated environments. Non-barred open-coast tidal flats are common in many temperate coastal areas (Reineck and Cheng, 1978 ; Mukherjee et al., 1987 ; Chun et al., 2000 ; Li et al., 2000 ; Yang and Chun, 2001). According to standard definitions, tidal flats are tide-dominated environments with a gentle slope, little wave influence, and welldeveloped tidal creeks (Reineck and Singh, 1980 ; Klein, 1985 ; Dalrymple, 1992), while beach and shoreface have relatively steep slope and experience strong wave action (Davis, 1985 ; Walker and Plint, 1992). The former shows distinct depositional characteristics : muddy heterolithic fa- 
cies including flaser, wavy and lenticular bedding, whereas the latter is typified as wave and storm-generated deposits including hummocky cross stratification (HCS) and swaley cross stratification (SCS).

Recent studies along the Chinese and South Korean coasts reveal that wave influence is an important factor in sedimentation on open-coast tidal flats (Li et al., 2000 ; Yang and Chun, 2001 ; Baek, 2002 ; Fan and Li, 2002). The macrotidal flat in Baeksu coast represents the depositional setting of open-coast macrotidal depositional system developed on the southwestern coast of Korea. The Chinese tidal flats described by Li et al. (2000) and Fan and Li (2002) are also those developed on non-barred setting. However, they differ from Korean examples in being much more sandy and getting more intensive modification from monsoon wind, warranting further detailed sedimentological study.

The majority of practical facies models for both modern and ancient tidal-flat successions show a fining-upward succession owing mostly to coastal progradation (Klein, 1971, 1985 ; Reineck and Singh 1980 ; Weimer et al., 1982 ; Elliott 1986 ; Middleton 1991 ; Dalrymple 1992). Such a coastal progradation is characteristic of most Holocene tidal flats worldwide, such as those of the North Sea (Evans 1965, 1975 ; Reineck, 1972, 1975 ; de Jong, 1977), the Bay of Mont-SaintMichel (Larsonneur, 1994), the Bay of Fundy (Knight and Dalrymple, 1975 ; Yeo and Risk, 1981 ; Dalrymple et al., 1990), and the Gulf of California (Thompson, 1968, 1975). These examples commonly exhibit a gradational fining-upward successions that ranges from subtidal or lowintertidal sands to high-intertidal or supratidal muds, except for the case of the Gulf of California where fine-grained sediments (silt and clay) are predominant. These prograding coastal successions are thought to occur in association with a relative sea-level falling where the rate of sediment supply exceeds the rate of creation of accommodation (Davis and Clifton, 1987 ; Posamentier and Allen, 1993). Most Holocene fi- ning-upward tidal-flat successions appear to be formed in areas of moderate to high sedimentation rate during sea-level rise.

Retrograding, coarsening-upward tidal flat successions have, however, been documented to be common on the west coast of Korea, especially in the western coasts of Korea (Frey et al., 1989 ; Korea Ocean Research and Development Institute 1991, 1994 ; Lee et al., 1994 ; Chang et al., 1996 ; Kim, 1997 ; Kim et al., 1999). Gomso Bay is also typical macrotidal flat in the southeastern open-coast setting that retains extensive tidal flats. It shows poor development of salt marshes and dendritic tidal drainage systems and lacks seaward depositional barriers compared to the counterparts of the North Sea (Korea Ocean Research and Development Institute, 1994). Together with these features, the coarseningupward lithology of Gomso Bay represents principal characteristics of the tidal-flat deposits in the southeastern coast of Korea, warranting high-resolution sequence stratigraphic studies of retrogradational tidal flat settings.

This paper aims to describe the response of tidal-flat sedimentation to the seasonal variation in the relative intensity between wave and tide influences, and to discuss characteristic features that may help to distinguish sandy, open-coast tidal flats from shoreface in the rock records. The objective of this study is also to report the importance of Holocene transgressive depositional model in the open-coast macrotidal setting for understanding its system and future.

\section{Environmental Setting}

The southwestern open-coast tidal flats are mostly 4-6 km wide and faces directly onto Yellow Sea. They are generally bordered on its landward side by rocky coastal cliffs or by artificial dykes that have been constructed to reclaim tidal marshes in a former embayment. These dykes inhibit the introduction of terrigenous sediment from landward sources. Tides are semi-diurnal (diurnal inequality of about $1 \mathrm{~m}$ ) with a mean spring range of $4.3-6.9 \mathrm{~m}$. The maxi- 


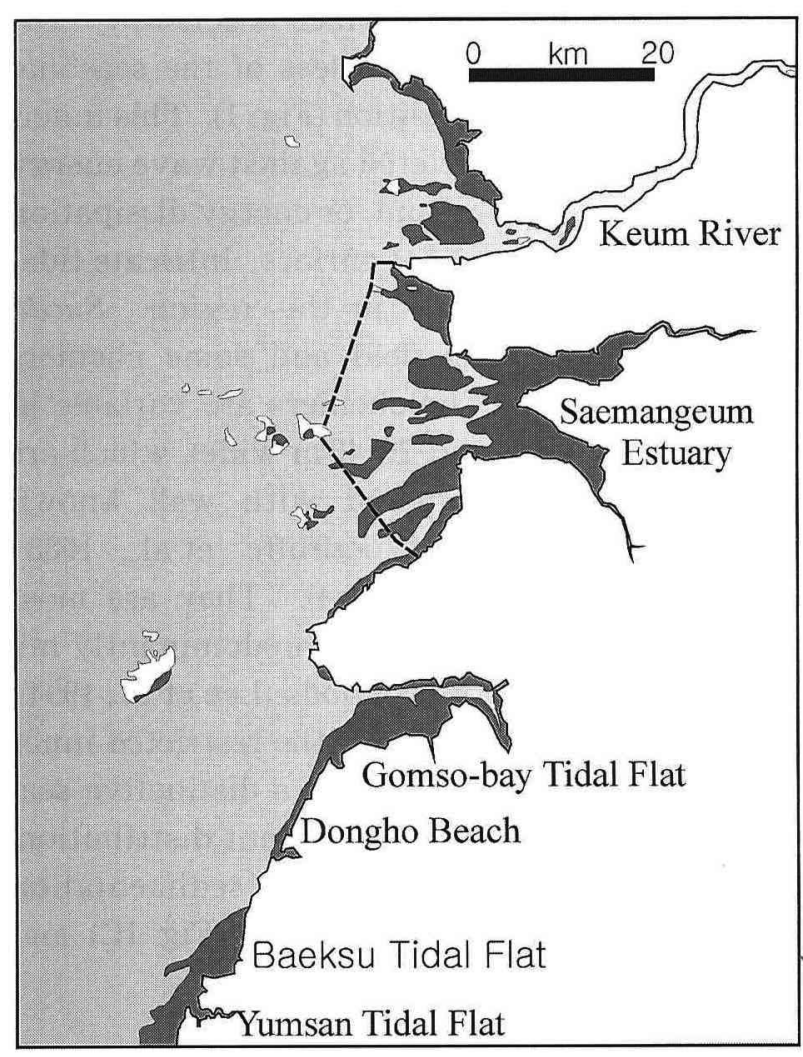

Fig. 1 Seasonal models of surface-sediment distribution (sedimentary facies) in the open-coast Baeksu (B), Yumsan (C) and Gomso-bay (D) intertidal flats. In winter and spring seasons, sand facies is dominant in the tidal flat due to heavy and strong wave action. In summer, mud flat gradually transgresses landward. Mud patches and ephemeral tidal creeks are formed in fall when wind wave increases again. mum current velocity is $1.0-3.2 \mathrm{kn}$ during spring tides and $0.8-3.1 \mathrm{kn}$ during neap tides, but speeds depend strongly on the wind magnitude and direction.

The wind in this coastal area shows a pronounced seasonality associated with monsoon. During the winter, winds blow mainly onshore from the NW to NNE with a mean speed of ca. $5-6 \mathrm{~m} / \mathrm{sec}$. In summer, by contrast, winds blow mainly from the south, in an obliquely offshore direction, with a mean speed of $2-3 \mathrm{~m} / \mathrm{sec}$ (Korea Meteorological Administration, 1997, 1998). Storms (defined as $>13.9 \mathrm{~m} / \mathrm{s}$ in wind speed) also display a pronounced seasonality, occurring less than 2-3 days/month during the summer, but more than 10 days/month during the winter, when waves with height of $1.5-2.0 \mathrm{~m}$ are common (Table 1). Typhoons $(>17 \mathrm{~m} / \mathrm{s}$ in wind speed) occur mainly during summer season which have been av. 1-3 times each year. Although some typhoons can produce waves up to $5 \mathrm{~m}$ high, the summer season is generally characterized by weak coastal waves with significant height of 0.5-1.0 m (Korea Meteorological Administration, 1997, 1998 ; National Fisheries Research and Development Institute, 1997, 1998). However, in winter, the onshore-directed winds generate significant wave height of $1.5-2.0 \mathrm{~m}$ on the flat. Some intertidal swash bars are developed on the upper intertidal flat, which are 100 to $300 \mathrm{~m}$ wide and 0.5 to $1 \mathrm{~m}$ high and migrate landward at

Table 1 Summary of wind data for the study area. Storms and typhoons are defined as periods with wind speeds $>13.9 \mathrm{~m} / \mathrm{sec}$ and $>17 \mathrm{~m} / \mathrm{sec}$, respectively. Although typhoons, which occur in the summer and early fall, have higher wind speeds than winter storms, only $17 \%$ of typhoons directly impact the west coast of Korea (Korea Meteorological Administration, 1997, 1998). As a result, the more frequent, but less intense, winter storms cause wave energy to be highest in winter.

\begin{tabular}{|c|c|c|c|c|c|c|c|c|c|c|c|c|c|}
\hline $\begin{array}{l}\text { Occurrence of Typhoons } \\
(1951-1998)\end{array}$ & 0.5 & 0.2 & 0.5 & 0.7 & 0.9 & $\bar{~} 1.8$ & 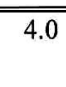 & $\begin{array}{l}5.7 \\
\end{array}$ & $\overline{5.0}$ & 4.1 & $\overline{2.6}$ & 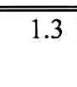 & 27.3/year \\
\hline $\begin{array}{l}\text { Effective Typhoons } \\
\text { (1904-1999) }\end{array}$ & - & - & - & - & 0.01 & 0.18 & 0.88 & 1.2 & 0.78 & 0.08 & - & & 3.13/year \\
\hline $\begin{array}{l}\text { Occurrence of Storm Wind } \\
(1997-1998)\end{array}$ & 10 & 6 & 6 & 4 & 2 & 2 & 3 & 2 & 6 & 6 & 7 & 9 & 63/year \\
\hline
\end{tabular}


rates of ca. $75 \mathrm{~m} / \mathrm{yr}$. These bars would be formed and migrated mostly by storms and typhoons.

\section{A Seasonal Model of Surface Sedimentation and Preservation Potential}

\subsection{A seasonal model of surface sediment dis- tribution}

The surface sediments in the open-coast intertidal flat can be classified into three types according to the sand/mud ratio: sand facies (sand, more than 70\%), mixed facies (sand, 40$70 \%$ ) and mud facies (sand, less than $40 \%$ ). Clay component in the surface sediments is characteristically very low throughout the year.

Most inner flats, composed mostly of mud facies (mostly silt sediments), are restricted within the narrow region from coastline to ca. $200 \mathrm{~m}$ away from the shore. Tidal beach is developed on the upper shore area of some sandy tidal flats (sandy inner flat) such as Dongho and Gamami beaches. The inner-flat surface is generally covered with silty mud regardless of the seasonal change of dynamic condition (Fig. 1). This innerflat zone has been sheltered against wave energy by its geomorphology and/or energy dissipation through shallow tidal flat surface. Intricate tidal creeks are formed only in this region. Sueda japonica (Halophytes) field and some cheniers occur in this flat. The cheniers are variable in size $(0.1-2 \mathrm{~km}$ long and $20-40 \mathrm{~m}$ wide), which are relatively small compared with well known worldwide cheniers (Woodroffe et al., 1983 ; Chappell and Grindrod, 1984). They are most probably of storm origin and predominantly migrate also during storm periods (Lee et al., 1994 ; Yang, 2000). Except only for the restricted inner flat area, the outer flat shows a distinctive seasonal variation of surface-sediment distribution.

The seasonal models of surface sedimentation in the Baeksu (Fig. 1B), Yumsan (Fig. 1C) and
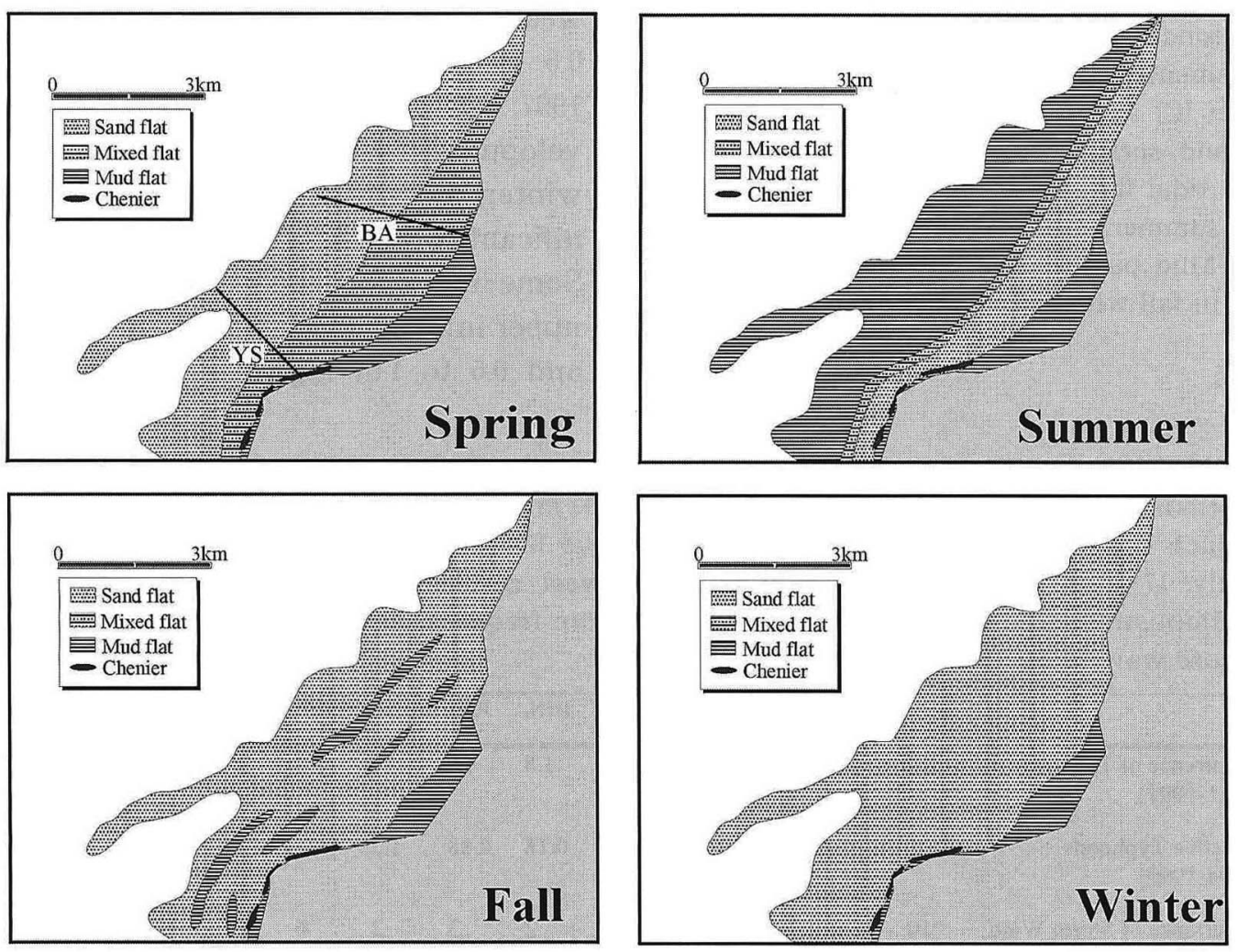

Fig. 1 (B). 

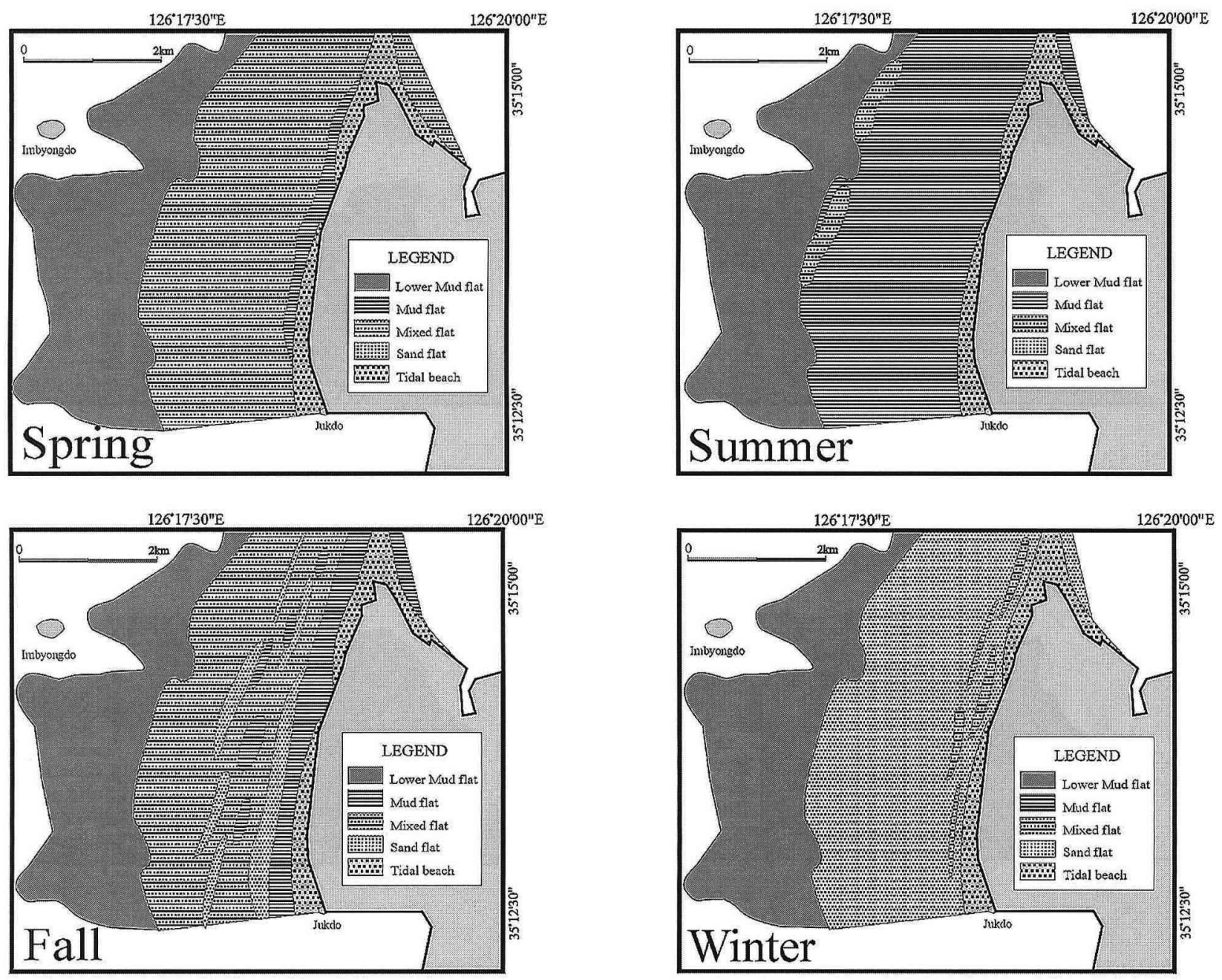

Fig. 1 (C).

Gomso (Fig. 1D) open-coast intertidal flats are completed. Most open-coast intertidal flats in the southwestern coast show a very similar pattern in seasonal change of surface sediment distribution even though it is variable according to their coastal geomorphology, tidal range and sediment supply. Here, the seasonal model in the Baeksu tidal flat is presented and explained as representative one of southwestern open-coast intertidal flats of Korea (Fig. 1). The seasonal change of surface sedimentary facies in the Yumsan and Gomso tidal flats refer to Figures 1 $\mathrm{C}$ and 1D.

\subsubsection{Spring}

In the spring season, the Baeksu intertidal flat can be divided into two distinctive zones except for relatively stable inner flat: sand-facies (0.2$1.3 \mathrm{~km}$ ) and mixed-facies $(>1.3 \mathrm{~km})$ zones (Figs. 2 $\mathrm{A}$ and 3 ). Sand content generally decreases toward subtidal zone with increasing mud content. Sand grains consist dominantly of very fine sand, and muds are composed mostly of coarse to medium silt. Sand content ranges $70-85 \%$ from shore to $1.3 \mathrm{~km}$, and $40-60 \%$ from $1.3 \mathrm{~km}$ to end of survey line (Fig. 3).

\subsubsection{Summer}

Surface sediments in the early summer domi- 
(A) Spring

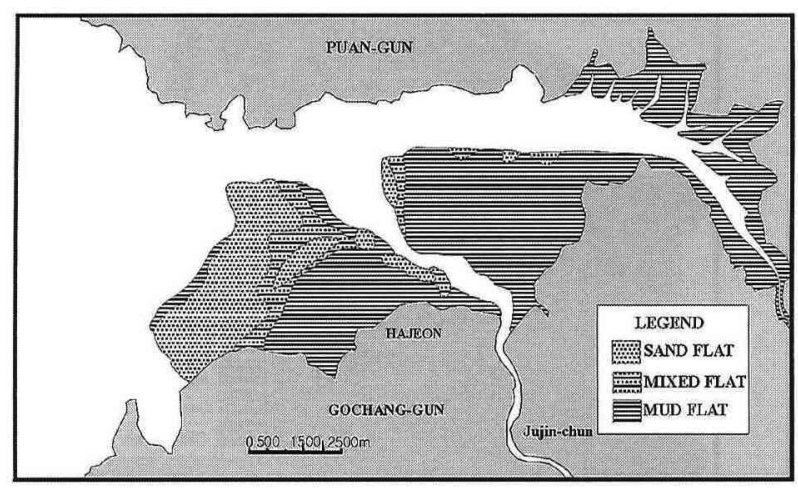

(C) Fall

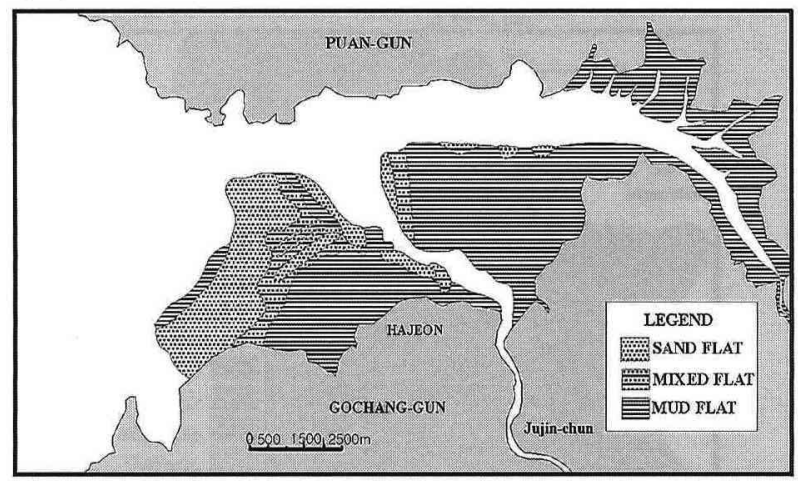

Fig. 1 (D).

\section{(B) Summer}

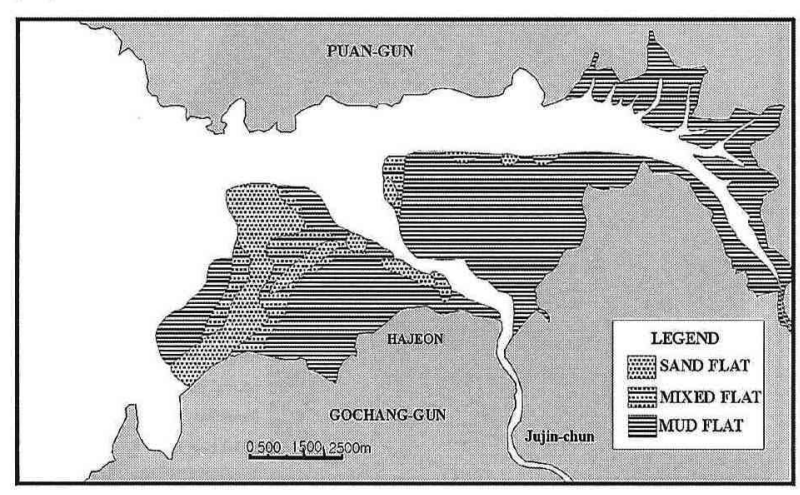

(D) Winter

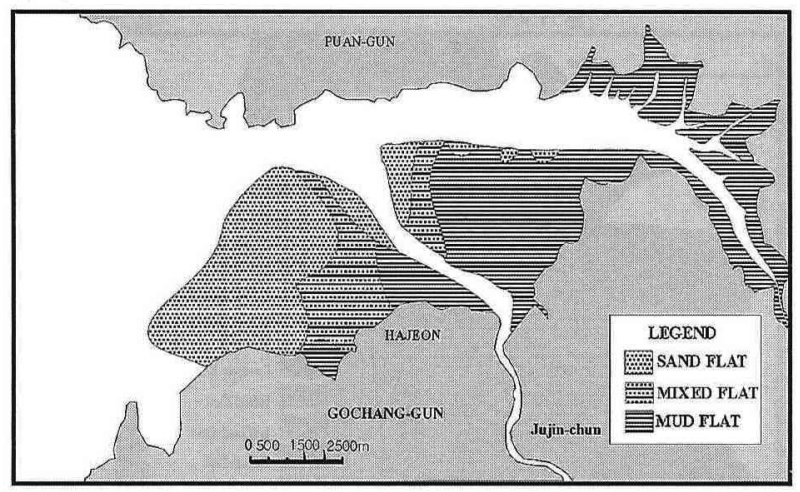

influenced by tidal currents with minor wave action. Furthermore, maximum solar insolation facilitates rapid drying and consolidation of finegrained sediments. Heterolithic stratification (including lenticular and tidal bedding) and homogeneous mud are the dominant deposit types.

\subsubsection{Fall}

The mud sediments, deposited in summer, have experienced severe erosion from early fall, probably caused by increased wave attack. Erosion takes place firstly in the upper flat and progresses into the middle flat, resulting in a textural change into sand facies (Figs. 2C, 3 and 4 ). The sand deposits typically show high amounts of mud fraction. Shallow tidal creeks and mud patches are formed on the sandy tidalflat surface. Whereas mud deposits in the lower ment (Krögel and Flemming, 1998). During the summer, tidal-flat sedimentation is dominantly 

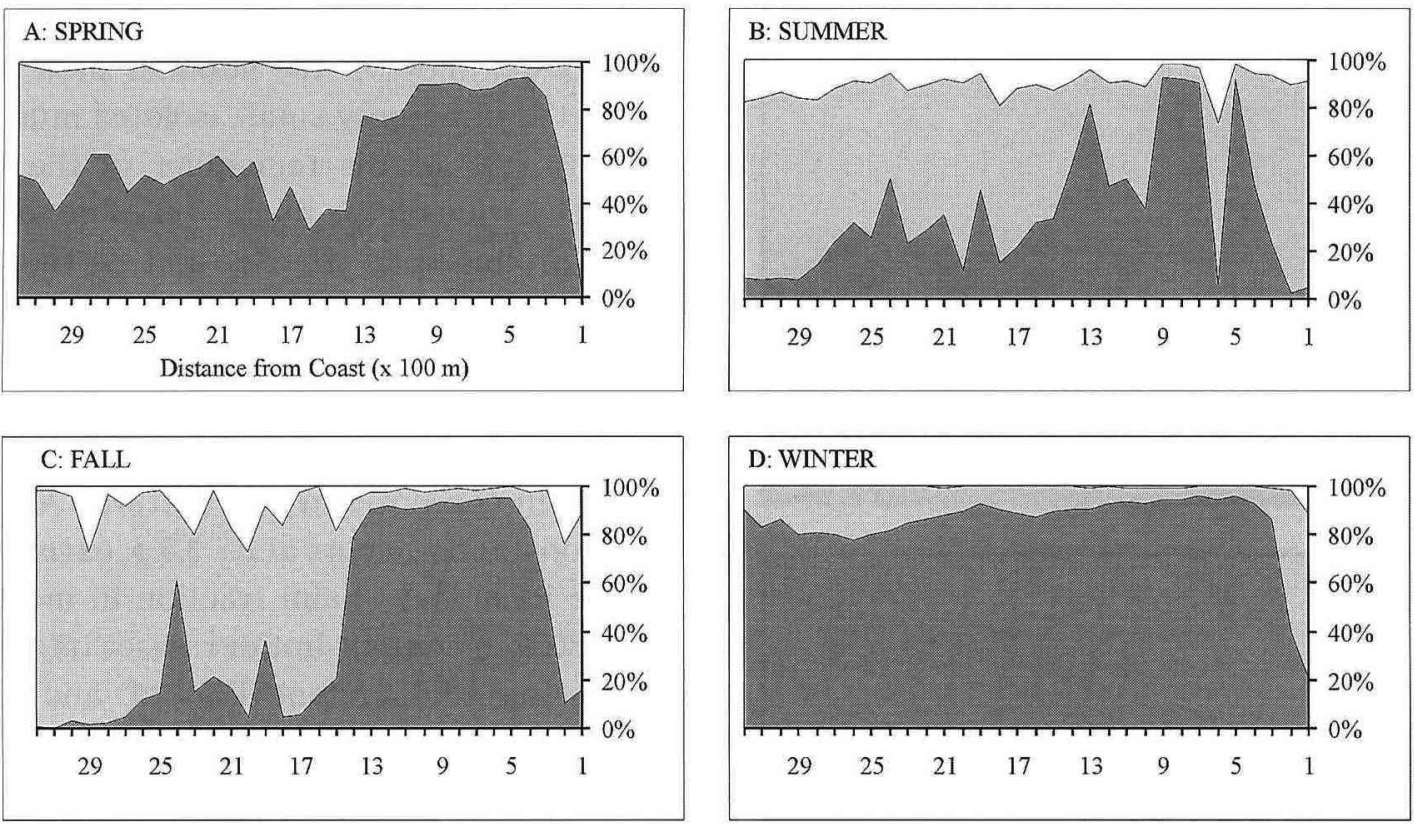

Fig. 2 Seasonal variation of relative grain-fraction ratio in surface sediment along the transect line BA during 1997 in the Baeksu intertidal flat. The most characteristic feature is a seaward fining trend with an increase in mud content at the cost of sand content toward offshore, unlikely those of other intertidal flats. Inner-flat $(<200 \mathrm{~m})$ sediment consists predominantly of muds with coarse-silt modal size (see Fig. 3 ).
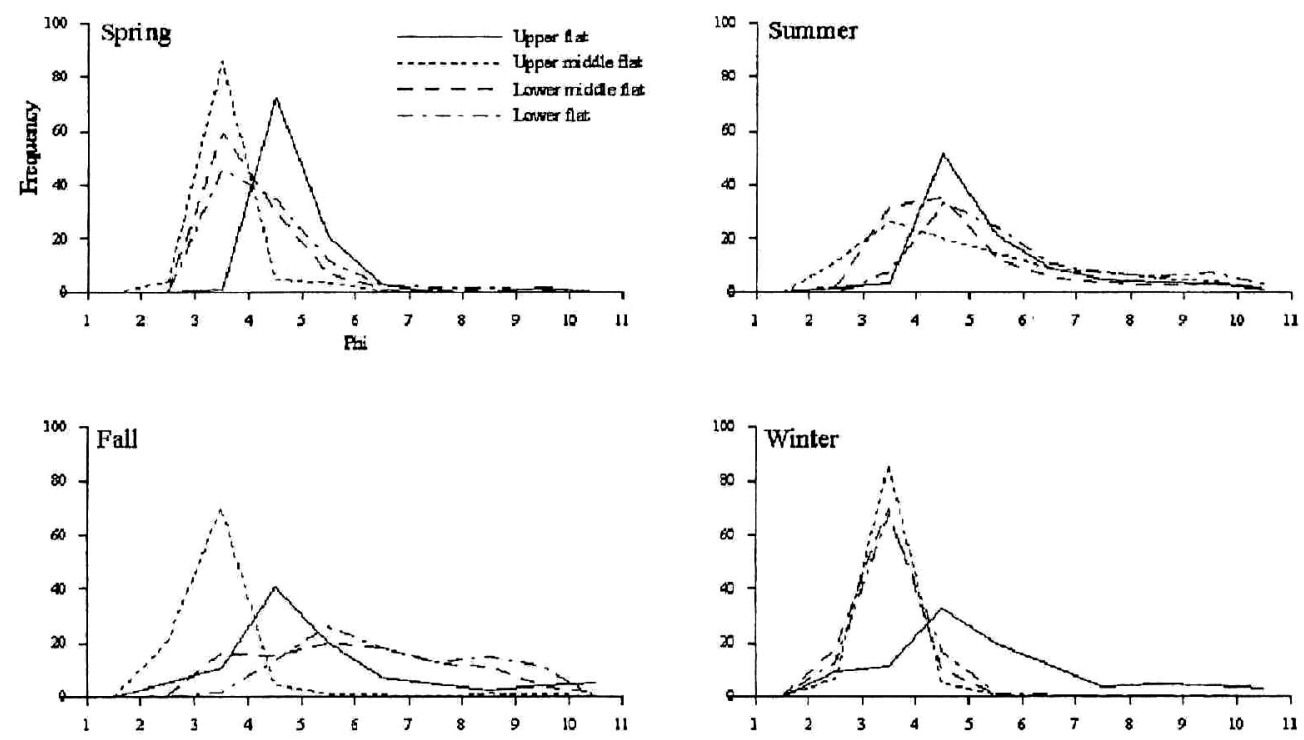

Fig. 3 Variation of grain size mode in the surface sediments of Baeksu flat. The highest sand content occurs in the spring and winter, whereas the finest mode occurs in the summer and fall.

and lower-middle flats $(>1.3 \mathrm{~km})$ remain uneroded and show a relative higher content of clay fraction than other seasons (Figs. 2C, 3).
The high contents of mud fraction in surface sediments suggest that some part of eroded fine sediments may be re-supplied through the 

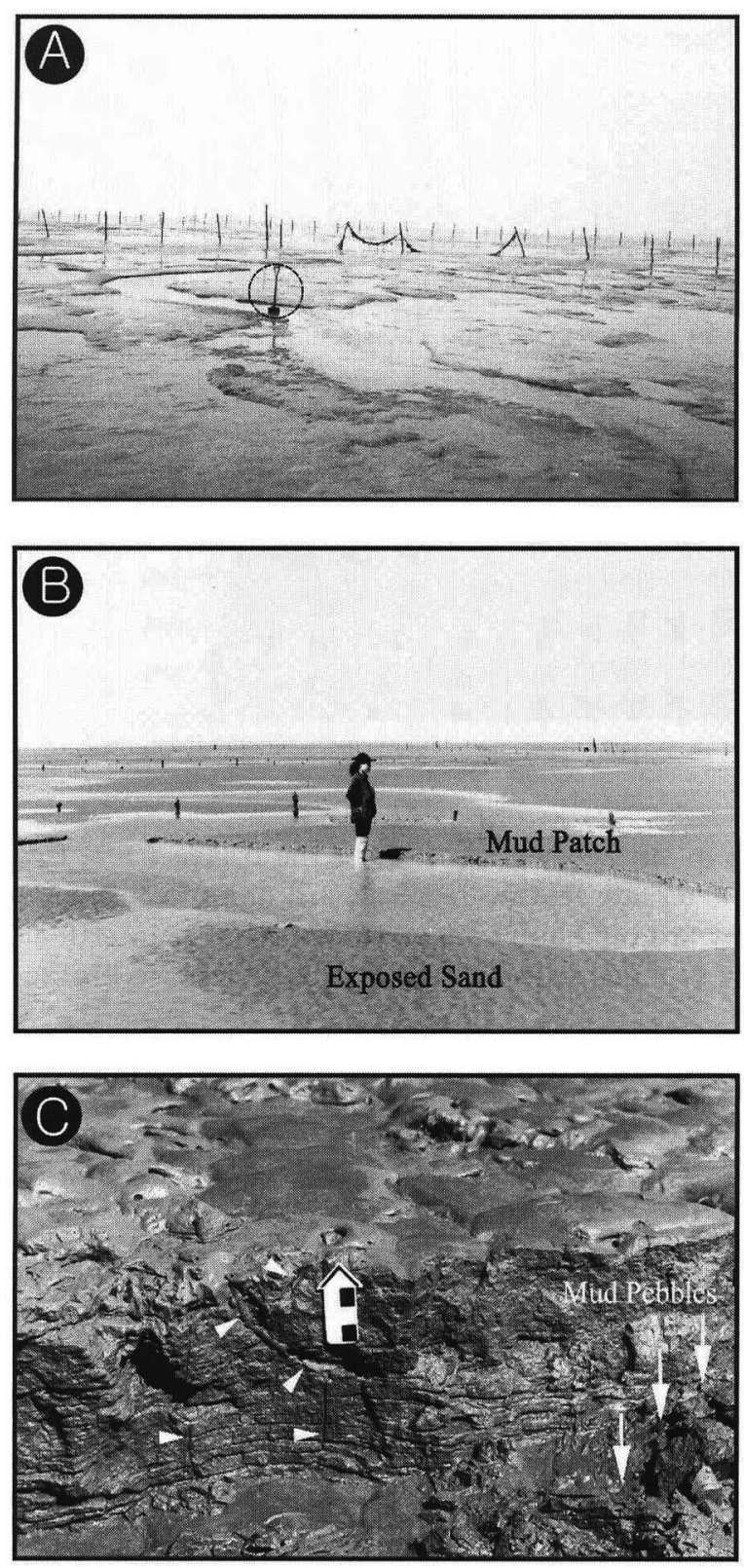

Fig. 4 Surface features of the Baeksu intertidal flat in fall season. Ephemeral tidal creeks are formed by erosion of mud layer due to increasing wind wave (A). Exposed sand flat and mud patches (B). Mud pebbles would be formed by breaking of mud patches due to attacks of strong wave (C). These pebbles are often preserved in subbottom under the condition of rapid sedimentation (Yang et al., 2000). Triangles indicate burrows, and large arrows indicate mud pebbles. Scale in $4 \mathrm{~cm}$ long. ephemeral tidal creeks (Fig. 4). By the end of the fall season, most of the summer mud has been eroded, leaving only small, isolated mud patches (Fig. 4). All of the remainder of the tidal-flat surface is covered by fine to very fine sand. Mud balls produced by the erosion of the summer mud are abundant at this time of the year.

\subsubsection{Winter}

In winter, the surface sediments are rather simple in composition and texture. Mean grain size constantly occurs at ca. $3.5 \phi$, except for that of the inner flat. Sand fraction in most flats is over $80 \%$ in content but decreases offshore with increasing mud content (Figs. 2D and 3). These grain-size distributions suggest that strong wave action would prevent suspended particles from settling down even on the upper flat. The extent of inner-flat mud sediments is reduced by expanding of sand flat, probably caused by strong bottom reworking by waves. Intense storm waves occur more than 10 days/month, resulting in the development of wave-generated parallel lamination, HCS \& SCS-like wavy stratification, and climbing wave-ripple lamination across the tidal flat (Fig. 5). The HCSs are notable for its short wavelength $(30-50 \mathrm{~cm})$, compared with that reported from offshore and shoreface deposits. Late-stage runoff current ripples are common, but these current-generated structures are easily reworked by storms; almost all preserved sedimentary structures are wave-generated. Bioturbation is extremely rare, except in the uppermost tidal flat where the wave energy is least. Surface sediments consist dominantly of well-sorted fine to very fine sand with minor silt. Mud pebbles are the only remnants of the summer mud layer. The preserved sedimentary structures closely resemble shoreface deposits.

\subsection{Other characteristics and preservation po- tential}

Regardless of seasonal change, the surface sediments on the open-coast intertidal flats in the southwestern Korea reveal a seaward fining 


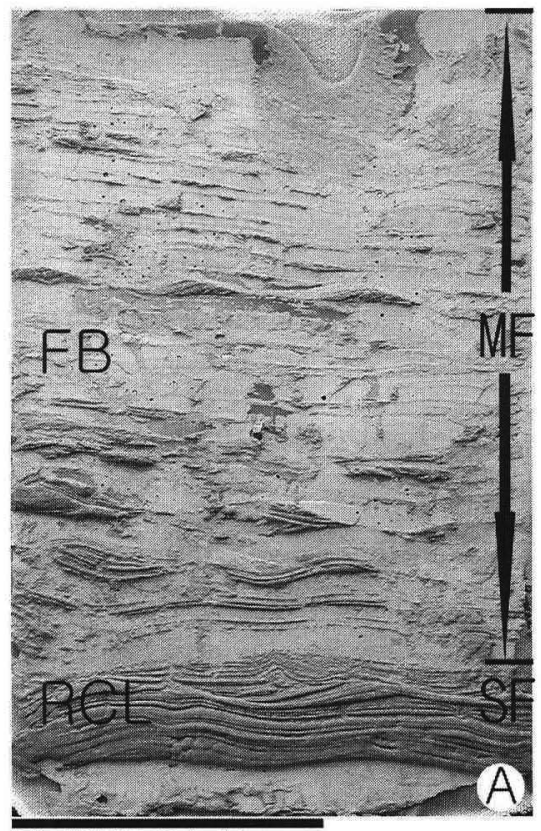

98. JULY, BA-31

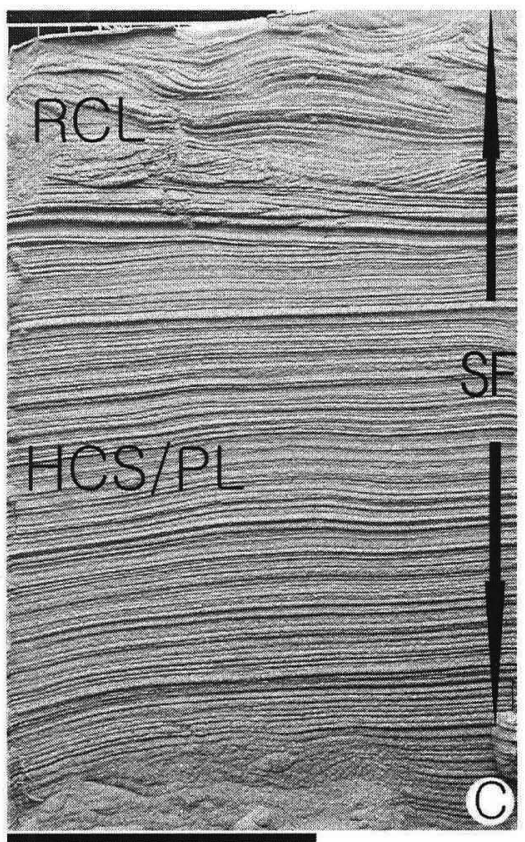

97. DEC. BA-27

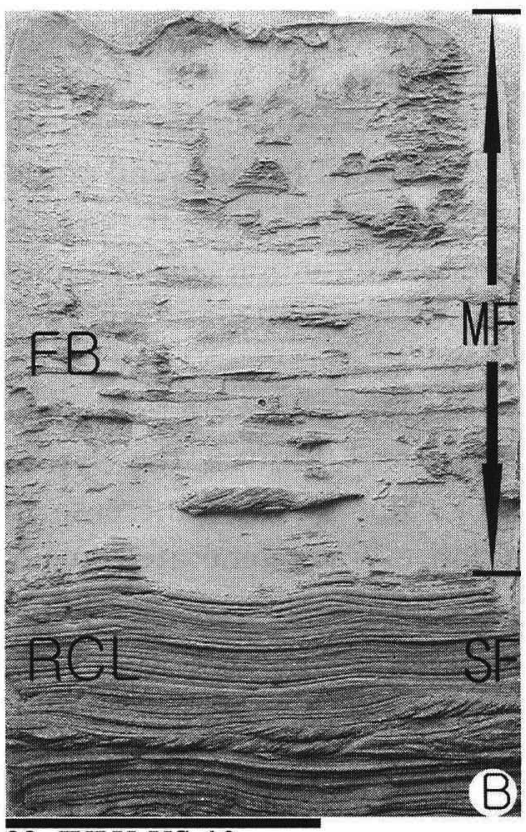

98. JULY, YS-10

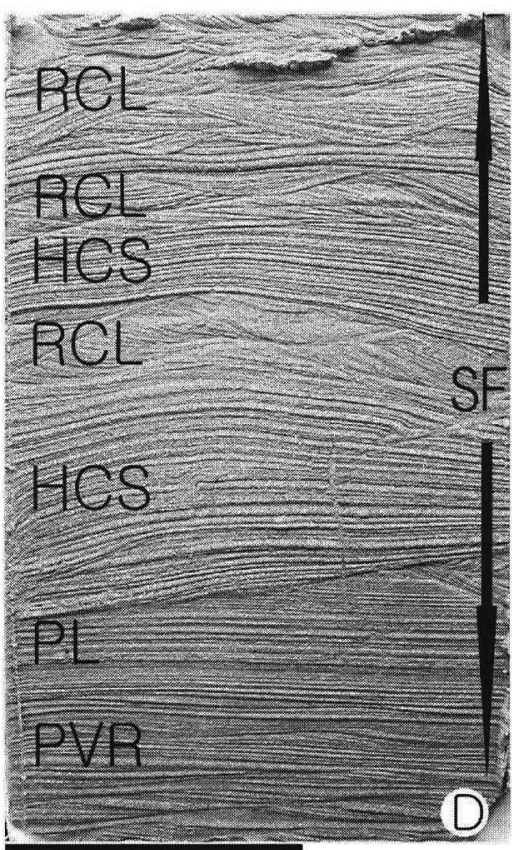

97. DEC. YS-28

Fig. 5 Cancore peels in the summer (A and B) and winter (C and D) in the Beaksu intertidal flat. Note that most sediments consist of mud-flat facies (FB, flaser bedding) in summer, whereas wave generated structures are conspicuous in winter. Peels of $\mathrm{C}$ and $\mathrm{D}$ (winter) consist mainly of stratified and slightly inclined stratified sand-flat facies. MF, Mud-flat Facies and SF, Sand-flat Facies; HCS, hummocky cross lamination; PL, parallel lamination ; RCL, ripple cross lamination; and PVR, post-vortex ripple. 
trend, unlikely to those in other tidal flats with almost all seaward coarsening trend (Reineck and Singh, 1980 ; Klein, 1985). It has not yet been understood how the seaward fining trend could be developed on the intertidal flat. It may be responsible for the combination of seasonal changes in relative ratio between wave and tidal energies.

The prevalence of strong northerly (obliquely onshore) winds decreases through the spring and the intervals of calm weather increase in number and duration. Wave-generated structures are produced during the storms, while muddy sediments consisting mainly of silt are deposited during the quiet periods when tidal processes dominate. Therefore, the spring deposits are characterized by mixed facies that are coarser grained, on average, than those of the summer season.

Most fine-grained, thick deposit formed during summer season would be not well preserved because it can be eroded easily by strong wave reworking during winter season. The upper part deposited in summer season (MF in Fig. 5A and $5 \mathrm{~B}$ ) is eroded out completely in winter period, resulting in dominance of upper-flow-regime plane bedded (PL in Fig. 5) and hummocky cross- stratified (HCS in Fig. 5) sand facies in preserved sections, except in the cores from inner flat areas. These sand facies are very similar to those in shoreface environments, consequently causing some confusion in differentiation between them characteristically different in recent environments, especially in the interpretation of ancient deposits.

\section{Depositional Model of Holocene Transgression}

\subsection{Holocene sea-level history}

The Holocene sea-level history in the coast of Yellow Sea has largely been derived from coastal stratigraphic work on the Chinese coast (Pirazzoli, 1991). Some sea-level curves, derived from elevations of coastal peat layers and ${ }^{14} \mathrm{C}$ dating, show a rapid rise in sea level from about $-40 \mathrm{~m}$ mean sea level (MSL) at the beginning of the Holocene to about $-10 \mathrm{~m}$ MSL around 7,000 yr BP. This was followed by gradual rise to present sea level, with minor oscillation of several meters (Yang and Xie, $1984 \mathrm{a}, \mathrm{b}$; Feng and Wang, 1986 ; Pirazzoli, 1991). Few reconstructions of Holocene sea level have been made for the western coast of the Korean Peninsula because of the scarcity of well-preserved coastal peats. A sea-

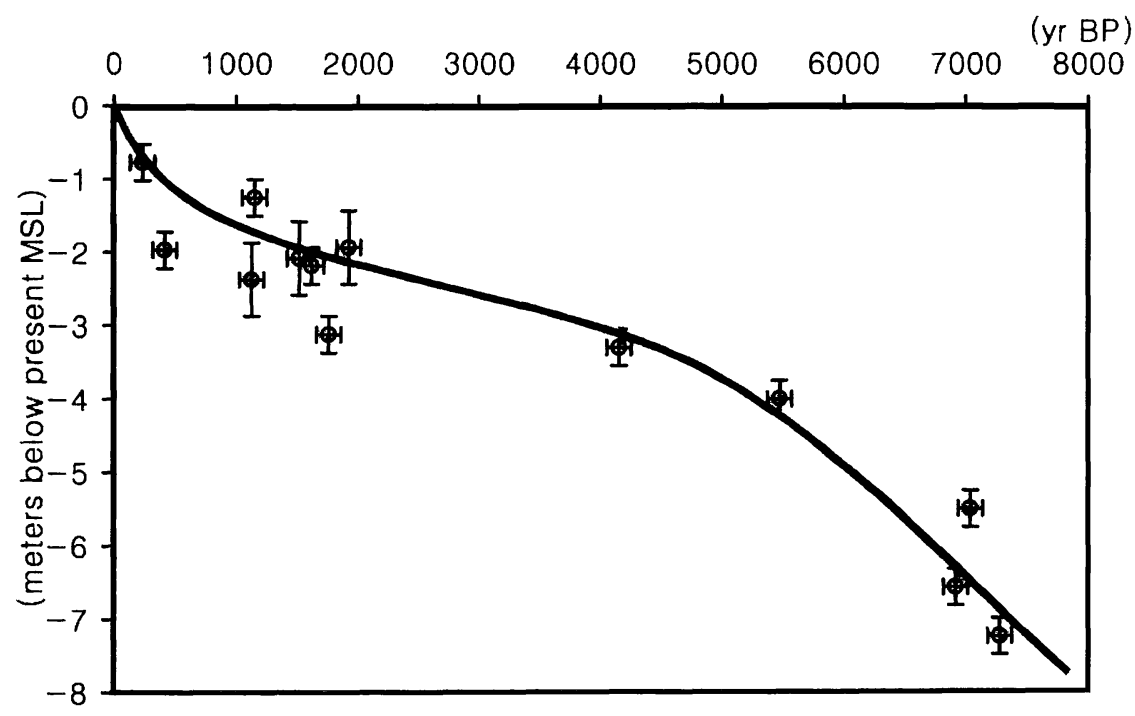

Fig. 6 Holocene sea-level change based on radiocarbon dates from the Gomso Bay deposits (open circles) (after Kim et al., 1999). 
level curve constructed by Bloom and Park (1985) based on ${ }^{14} \mathrm{C}$ data from the Korean western coast displays a gradual rise from $-8 \mathrm{~m}$ mean high water level around $8,500 \mathrm{yr} \mathrm{BP}$ to $-2 \mathrm{~m}$ around 5,000 yr BP and a gradual rise thereafter.

A Holocene sea-level curve was constructed in Gomso Bay based largely on radiocarbon dates obtained from plant remains, peats and shells (Fig. 6 ; Kim et al., 1999). The paleo-MSL level was determined using the assumption that tidal range and frequency, wave regime and bathymetric slopes in Gomso Bay have changed little during the mid to late Holocene. It was also assumed that the distribution of subenvironments within the tidal flat has been controlled primarily by water depth. The curve shows that paleo-MSL on the western coast of Korea had a relatively rapid rise (at a rate of approximately $1.3 \mathrm{~mm} / \mathrm{yr}$ ) from $-7 \mathrm{~m}$ to $-5 \mathrm{~m}$ between $7,000 \mathrm{yr}$ $\mathrm{BP}$ and 5,500 yr BP, and then rose gradually at an average rate of $0.9 \mathrm{~mm} / \mathrm{yr}$ to the present.

Holocene sea-level change can also be reconstructed from the lithostratigraphic and chronostratigraphic analysis of the Gomso tidal-flat deposits. On the basis of the ${ }^{14} \mathrm{C}$-derived mean accumulation rates $(0.2-0.3,0.5-0.6$, and $1.5-2.0$ $\mathrm{mm} / \mathrm{yr}$ for the mud flat, mixed flat and sand flat, respectively), two isochrons (paleo-surfaces) are assumed for the age of 1,100 $\mathrm{yr} \mathrm{BP}$ and $1,800 \mathrm{yr} \mathrm{BP}$ (Fig. 7). In Figure 7, the line connecting the mixed-sand flat contact in cores is the locus for points of a constant paleo-water depth equal to that of the present-day lithofacies boundary between the superficial sediments of the mixed flat and sand flat, i.e., each point on the line formed about $\pm 0.5 \mathrm{~m}$ below MSL. The intersection point of the mixed-sand flat boundary with the $1,800 \mathrm{yr} \mathrm{BP}$ isochron is $3 \mathrm{~m}$ deeper than the present-day boundary (Fig. 7). This suggests that paleo-MSL at 1,800 yr BP was $3 \mathrm{~m}$ lower than the present MSL. The gradual updip and landward migration of the boundary through time suggests that sea level has risen continuously since 1,800 yr BP, without any significant fluctuating episodes of sea-level fall. This curve could be adopted for the understanding the sea-level change and the evolution of sedimentation in the southwestern open coasts of peninsula (eastern Yellow Sea).

\subsection{Models for prograding vs. retrograding tidal-flat deposits}

Progradational, fining-upward facies successions are classic, standard models for both modern and ancient intertidal deposits. These successions have been well documented from the tidal flats of the North Sea and Bay of Fundy. On the North Sea coast, broad, gently dipping tidal flats generally consist of shore-parallel subtidal, intertidal, and supratidal subzones (Reineck, 1972 ; de Jong, 1977 ; Klein, 1985 ; Reineck and Singh 1980). Although relative sea level in the

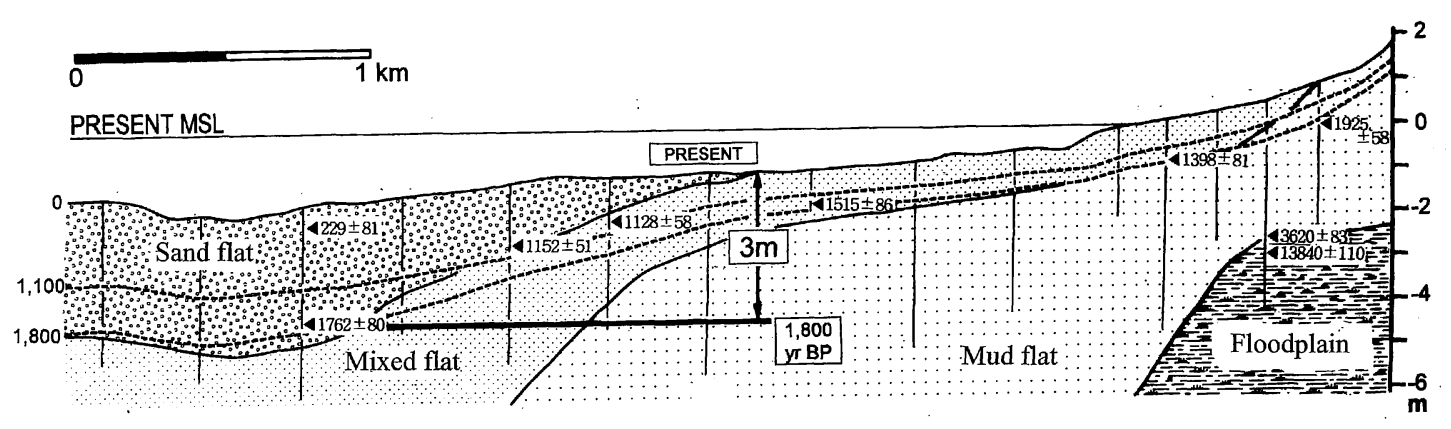

Fig. 7 Simplified stratigraphic cross section of the Gomso tidal flat, showing retrograding, coarsening-upward Holocene marine succession underlain unconformably by non-marine deposits. Solid vertical lines represent vibracores. Numbers beside arrow heads depict radiocarbon dates on shells and plant remains (modified after Kim et al., 1999). 


\section{Jade Bay}

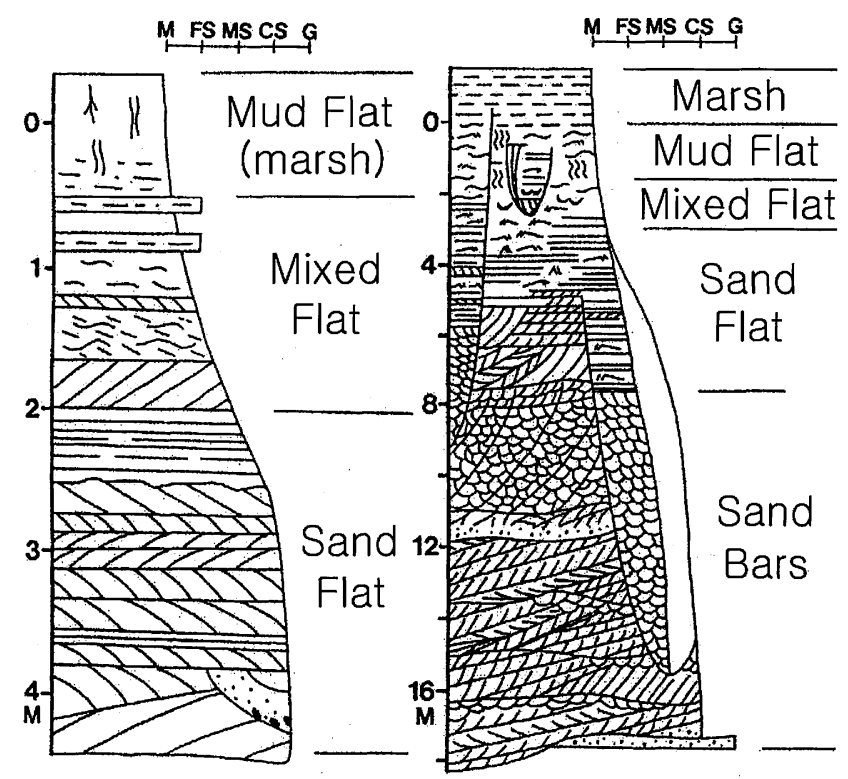

Gomso Bay

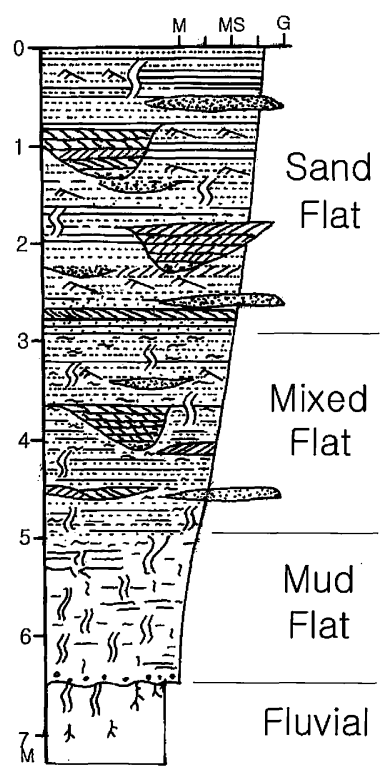

Fig. 8 Facies models for tidal flats of the North Sea (Jade Bay) and Bay of Fundy, showing fining-upward succession by coastal progradation (modified from Klein, 1977, and Dalrymple et al., 1990), and facies model for tidal flats of the Gomso-bay tidal flat, showing coarsening-upward succession by coastal retrograding with sea-level rise.

North Sea rose rapidly during the early to mid Holocene ( $>10 \mathrm{~mm} / \mathrm{yr}$, prior to about $6,000 \mathrm{yr} \mathrm{BP}$ ) and subsequently fell during the mid to late Holocene ( $1 \mathrm{~mm} / \mathrm{yr}$ ) (Van de Plassche and Roep 1989 ; Beets et al., 1992 ; Van der Spek and Beets 1992), Holocene tidal flats of the North Sea are generally characterized by coastal progradation due to high sediment input (Klein 1977, 1985). Continuous progradation has generated a finingupward tidal-flat succession (Fig. 8). This succession consists of a dominantly sandy subtidal zone of channel-fill, point bar and shoal sediments; mixed sand and mud intertidal-flat deposits, and muddy high-tidal-flat and salt-marsh deposits (Klein, 1977 ; Reineck, 1972). A decrease in grain size can also be seen within the individual subfacies.

A progradational tidal-flat succession also developed in the macrotidal Cobequid Bay-Salmon River estuary in the Bay of Fundy during the Holocene. The deposits in the inner estuary consist of an axial belt of sands flanked by mud flat and salt marsh (Dalrymple et al., 1990). Despite a relatively rapid rise of sea level over the last 4,000 years (more than $1 \mathrm{~mm} / \mathrm{yr}$; Scott and Greenberg, 1983), the tidal flats in the Bay of Fundy have also built a prograding fining-upward succession because of high sediment input (e.g., $1.15-9.25 \times 10^{6} \mathrm{~m}^{3} / \mathrm{yr}$; Amos and Long, 1980). Progradation has produced a 20 -m-thick, finingupward succession (Dalrymple et al., 1990 ; Fig. 8) with a base that is marked by a gravel lag which formed in subtidal zone. Sands overlying the lag fine upward from coarse sand at the bottom of deeper channels to the medium sand of bar crests, and then to the fine sand of sand flat. These sands are, in turn, overlain by the increasingly muddy sediments of the mixed flat, mud flat, and salt marsh.

Retrogradational, coarsening-upward tidal-flat successions have been less frequently documented (e.g., Reineck, 1972 ; Yeo and Risk, 1981 ; 
Frey et al., 1989). From analyses of the vibracores from the Gomso tidal flat, a generalized model can be developed for retrogradational tidal-flat successions in storm-influenced, macrotidal settings (Fig. 8). It comprises a coarseningupward succession of three principal depositional environments that record a retrogradational trend from mud at the base to sand to the top. This is a lithological trend that is exactly opposite to that of the general facies models for prograding tidal flats.

Depositional response of the Jade Bay (North Sea), Bay of Fundy, and Gomso Bay tidal flats to Holocene sea-level rise appear to be influenced mainly by the interaction of accommodation and sediment supply (cf. Posamentier et al., 1988; Van Wagoner et al., 1990 ; Schlager, 1993). The rate of relative sea-level rise during the mid to late Holocene is similar in all three areas (Fig. 6 ; Amos 1978; Scott and Greenberg 1983; Amos and Zaitlin 1985; van de Plassche and Roep, 1989 ; Beets et al., 1992 ; van der Spek and Beets 1992 ; Korea Ocean Research and Development
Institute, 1994). However, the rate of accumulation was quite different in the three areas. The mean Holocene accumulation rate in intertidal flats was much lower in Gomso Bay $(0.2-2.0 \mathrm{~mm} /$ yr) than in the North Sea $(3-10 \mathrm{~mm} / \mathrm{yr}$ : Reineck, 1963, 1969 ; McCave 1970 ; Eisma 1981) and Bay of Fundy (5-50 mm/yr : Amos and Long, 1980 ; Dalrymple et al., 1990, 1991). Such a low accumulation rate is most likely responsible for the retrogradational nature in the Gomso tidal deposits during the mid-to-late Holocene transgression (Fig. 9).

\subsection{Sedimentological and stratigraphic impli- cations}

The retrogradational, coarsening-upward succession in the storm-influenced, macrotidal flat in the southwestern coast of Korea also differs from the progradational, coarsening-upward successions in high-energy shoreface environments, especially when the latter are associated with macrotidal beach, as in New South Wales-Queensland, Australia (Wright and Short,

\section{(A) High sediment input}

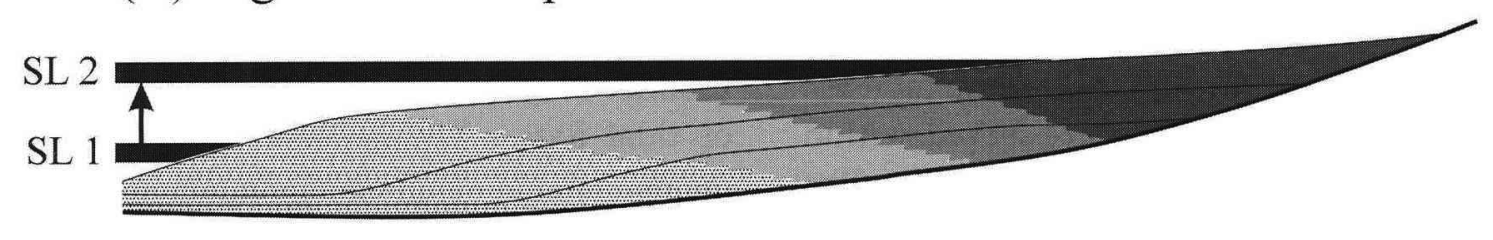

\section{(B) Low sediment input}

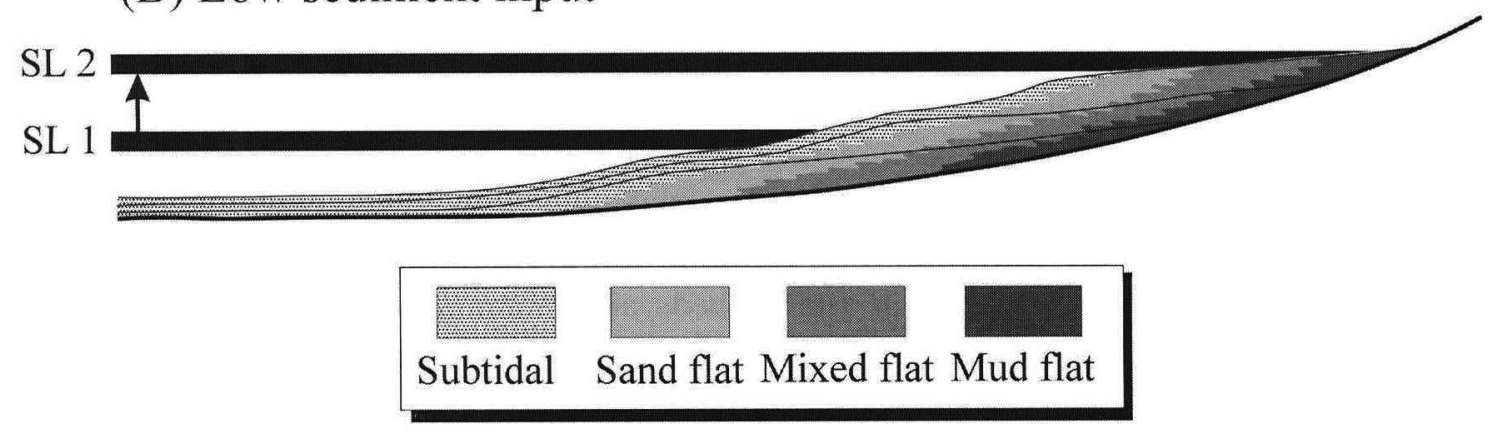

Fig. 9 Schematic cross sections showing the evolution of tidal-flat successions during sea-level rise. A) Classic North Sea and Bay of Fundy model, in which progradation occurs during sea-level rise because of high sediment input, and B) Model for the southwestern open coasts of Korea, in which retrogradation occurs during sea-level rise because of low sediment input. 
1984 ; Short, 1991). Although these progradational macrotidal beach-shoreface deposits show a similar coarsening-upward trend, they consist entirely of sands, usually from fine sand at the base to medium to coarse sand at the top. This is partly because the macrotidal beach environments are always affected by wave action, whereas the Gomso tidal flat with substantial muds is only intermittently influenced by storm waves. One key element to help distinguish the two successions in the rock record may therefore be the presence or absence of interlayered mud deposits and some bi-directional structures in the succession.

The fining-upward tidal-flat successions in the North Sea and the Bay of Fundy conform to the definition of parasequences. Parasequences are generally characterized by progradational and shoaling-upward associations of sedimentary facies, bounded by marine flooding surfaces that represent abrupt increases in water depth (Van Wagoner et al., 1990). However, the Holocene coarsening-upward tidal deposits in Gomso Bay, although part of a parasequence, suggest retrogradational deposition during Holocene sea-level rise. This is out of accord with the classic concept of the sequence stratigraphers that vertical facies associations indicating a gradual increase in water depth have not been observed within parasequences (Van Wagoner et al., 1990). The transgressive macrotidal deposits above the flooding surface in Gomso Bay should, however, be considered as the base of the ongoing, or probably overlying, retrograding parasequence, like that described in the wave-dominated shoreface succession by Arnott (1995).

\section{New Classification of Coastal Environment}

Sandy open-coast tidal flats common in the southwestern Korean coasts correspond to intermediate clastic coastal environment between the wave- and tide-dominated end members of the coastal spectrum (Fig. 10). This type of tidal flats has not been well studied but it is relatively common in temperate regions. Its sandy winter deposits have high preservation potential compared with summer ones, causing some difficulties as examined ancient columns of shoreface environments. Therefore, the transitional type of the open-coast tidal flats, together with tidal beaches, should be added to the range of depositional models for coastal deposits.

\section{Discussion and Conclusions}

The open-coast tidal flat in the southwestern coast of Korea is transitional between sheltered tidal flats and beaches/shorefaces (Fig. 10 ; cf. Hayes, 1979 ; Short, 1991 ; Boyd et al., 1992 ; Harris et al., 2002). In summer season when wave action is minimal, it behaves much like a typical tidal flat, accumulating muddy tide-dominated and heterolithic deposits (Fig. 5). During the winter, sedimentation is controlled mainly by breaking waves, resulting in dominant accumulation of graded storm beds that contain parallel lamination, hummocky cross stratification (HCS/SCS) and wave ripples. They are very similar to the deposits formed in the shoreface (Walker and Plint, 1992). The concave-upward topographic profile and onshore increase in sand portion are also similar to those in shoreface environment although the presence of inner mudflat in sheltered areas is more characteristic of tidal flats. The general scarcity of muddy deposits in the deeper parts of the cancores from the outer flats (Fig. 5), regardless of the season, indicates that preserved units has been formed under dominantly wave-dominated regime in the longer term. The preservation potential of the muddy heterolithic facies is very low as a result of intense erosion by storms during fall and winter seasons. As a result, the preserved deposits are dominated by amalgamated storm beds and resemble shoreface successions. This raises the question of whether many ancient "shorefaces" are, in fact, open-coast tidal flats or not.

Transitional coastal environments, that lie between the end members of sheltered tidal flat and beach/shoreface, are probably much more 


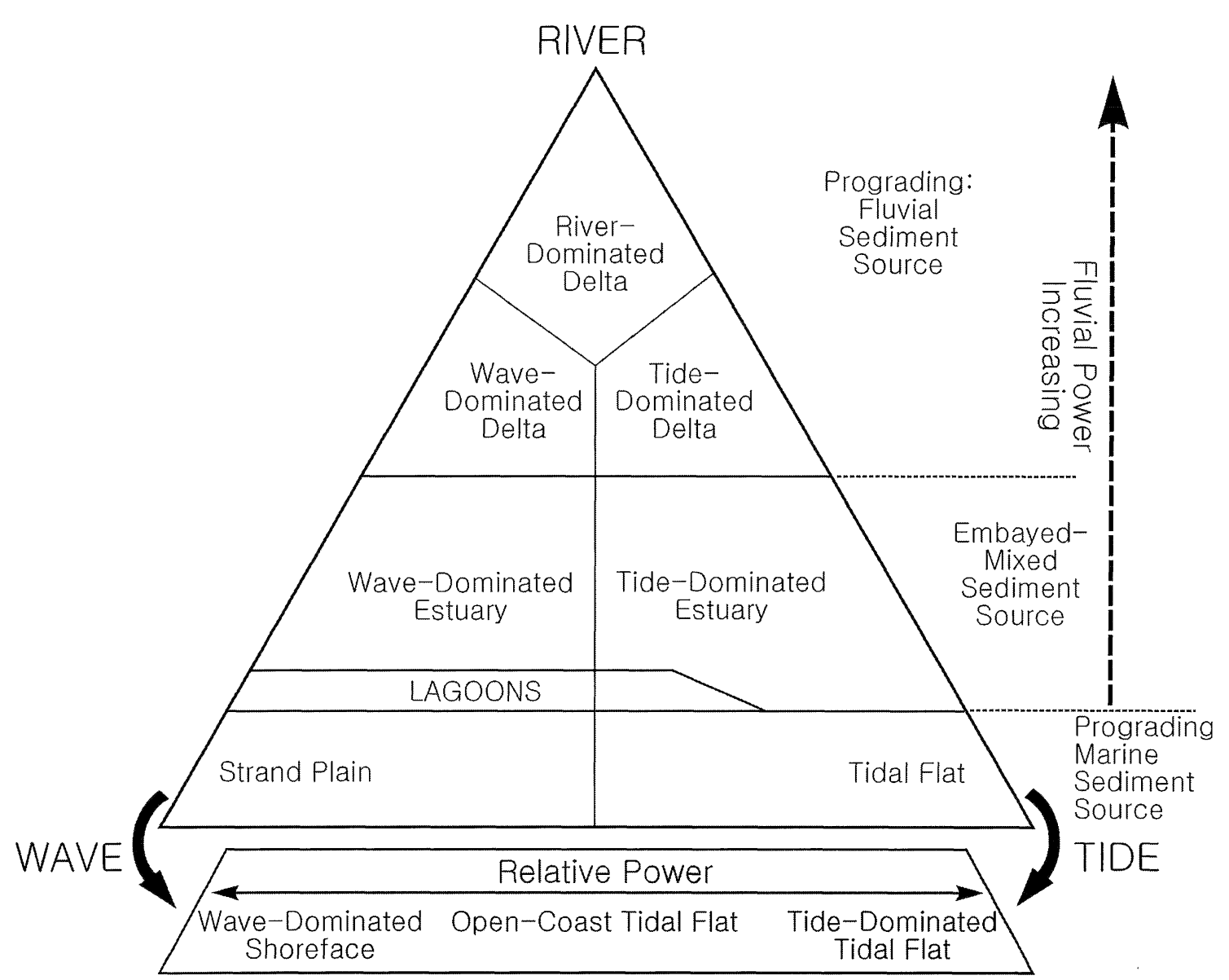

Fig. 10 Classification of clastic coastal environments. It should be noted that sandy, open-coast tidal flats are intermediate between the wave- and tide-dominated end members of the coastal spectrum.

common than the available literatures have indicated. Sandy open-coast tidal flats (see also Reineck and Cheng (1978), Mukherjee et al. (1987) and Baek (2002)) and tidal beaches are included in this transitional setting. All of these settings show a concave-up profile. The tidal beaches described by Short (1991) and Masselink and Short (1993) have a relatively steep beach face that ranges from $0.5^{\circ}$ to $3^{\circ}$ in slope. The opencoast tidal flats in the northeastern India have a slope of ca. $0.15^{\circ}$ (Mukherjee et al., 1987), while the Baeksu tidal flat has an average slope of $0.06-0.07^{\circ}$. In general, swash bars become dominant with increasing of slope, while the presence of an inner mudflat is more common on low- gradient coasts. This spectrum of environment presumably reflects a gradient of wave energy, with the steeper slopes occurring where the wave energy is higher (Wright and Short, 1984). Sediment grain size is also closely associated with the coastal gradient: coarser grain sizes promote steeper slopes (Davis, 1985 ; Short, 1991). Thus, open-coast tidal flats and tidal beaches can be well formed broadly under the same wavetide regime.

As already mentioned, the preserved deposits in the Baeksu tidal flat show significant similarities with those of typical shoreface. However, based on detailed observation, there are a number of features that can differentiate the deposi- 
tional characteristics between open-coast tidal flats and shorefaces : 1) mud pebbles at the bases of storm beds ; 2) ripple-scale herringbone crosslamination; 3) flood-dominated climbing ripples ; 4) HCS/SCS with shorter wave length than that of shoreface to shelf deposit ; 5) gently inclined parallel lamination ; and 6) upward gradation of sandy deposit into muddy tidal-flat deposit. However, they need to be further detailed studies to supply the good diagnostic criteria.

In summary, the sandy open-coast tidal flats in the southwestern coast of Korea, have experienced a typical seasonal variation in sedimentary conditions, oscillating between tidal-flat sedimentation in summer and shoreface-like wave-dominated condition in winter. In the longer term, most preserved deposits are those formed under wave-dominated regime. These are similar to, but subtly different from those of true shoreface deposit. Such an open-coast tidalflat setting has rarely been recognized in the rock record, indicating that some records could have been mis-identified as shoreface deposit.

The retrograding, coarsening-upward late Holocene succession recorded in the southwestern tidal flat resulted largely from low sedimentation rates under low to moderate rates of sealevel rise. This contrasts with the classic prograding, fining-upward intertidal successions developed in the North Sea and Bay of Fundy. This model suggests that most coasts in southwestern coast of Korea would have much higher potential to experience coastal erosion and inundation with the future sea-level rise than the coasts developed under high sediment supply. It is also helpful for the coastal management in these coastal areas.

\section{Acknowledgements}

The research was supported through the grant to S. S. Chun by the Korea Science and Engineering Foundation (R01-2001-00081).

\section{References}

Amos, C.L., 1978 : The post-glacial of the Minas Basin, Nova
Scotia : a sedimentological interpretation. Journal of Sedimentary Petrology, 48, 965-982.

Amos, C.L. and Long, B.F. N., 1980 : The sedimentary character of the Minas Basin, Bay of Fundy. In McCann, S. B., ed., The Coastline of Canada, Geologic Survey of Canada, Paper 80-10, 153-180.

Amos, C.L. and Zaitlin, B. A., 1985 : The effect of changes in tidal range on a sub-littoral macrotidal region, Bay of Fundy, Canada. Geo-Marine Letters, 4, 161-169.

Arnott, R. W. C., 1995 : The parasequence definition- are transgressive deposits inadequately addresses? Journal of Sedimentary Research, B65, 1-6.

Baek, Y.S., 2002 : Seasonal variation of depositional characteristics of surface sediment and sedimentary facies in the Yumsan intertidal flat, southwestern coast of Korea. Unpubl. MSc. Thesis, Chonnam National University, 76 p. (in Korean)

Beets, D.J., Van der Valk, L. and Stive, M.J.F., 1992 : Holocene evolution of the coast of Holland. Marine Geology, 103, 423-443.

Bloom, A. L. and Park, Y. A., 1985 : Holocene sea-level history and tectonic movements, Republic of Korea. Quaternary Research of Japan, 24, 77-84.

Boyd, R., Dalrymple, R.W. and Zaitlin, B. A., 1992 : Classification of clastic coastal depositional environments. Sedimentary Geology, 80, 139-150.

Chang, J.H., Park, Y. A. and Han, S. J., 1996 : Late Quaternary stratigraphy and sea-level change in the tidal flat of Gomso Bay, west coast of Korea. The Journal of the Korean Society of Oceanography, 1, 59-72.

Chappell, J. and Grindrod, J., 1984 : Chenier plain formation in Northern Australia. In Thom, B. G., ed., Coastal Geomorphology in Australia, Academic Press, Sydney, 197-231.

Cheel, R.J. and Leckie, D. A., 1993 : Hummocky cross-stratification. In Wright, V.P., ed., Sedimentology Review, Blackwell Science, Oxford, no. 1, 103-122.

Chun, S.S., Yang, B.C., Lee, I.T. and Lee, H.J., 2000 : Nonbarred, open macrotidal flats strongly influenced by wave action, Gomso Bay and Baeksu Coast, Southwest Korea: Depositional processes, seasonal evolution and transgressive stratigraphy. Tidalite 2000, 5 th International Conference on Tidal Environments, Field Guide Book (B2), $101 \mathrm{p}$.

Dalrymple, R.W., 1992 : Tidal depositional systems. In Walker, R. G. and James, N.P., eds., Facies Models : Response to Sea-Level Change, Geological Association of Canada, 195218.

Dalrymple, R. W., Knight, R. J., Zaitlin, B. A. and Middleton, G. V., 1990 : Dynamics and facies model of a macrotidal sand-bar complex, Cobequid Bay-Salmon River Estuary (Bay of Fundy). Sedimentology, 37, 577-612.

Dalrymple, R. W., Makino, Y. and Zaitlin, B. A., 1991 : Tempo- 
ral and spatial patterns of rhythmite deposition on mud flats in the macrotidal Cobequid Bay-Salmon River Estuary, Bay of Fundy, Canada. In Smith, D. G., Reinson, G. E., Zaitlin, B.A. and Rahmani, R. A., eds., Clastic Tidal Sedimentology, Canadian Society of Petroleum Geologists Memoir, no. 16, 137-160.

Davis, R. A. and Clifton, H.E., 1987 : Sea-level change and the preservation potential of wave-dominated and tidedominated coastal sequence. In Nummedal, D., Pilkey, O. H. and Howard, J.D., eds., Sea-Level Fluctuation and Coastal Evolution, SEPM Special Publication, no. 41, 167178.

Davis, R. A., Jr., 1985 : Coastal Sedimentary Environments. 2nd ed. Springer-Verlag, New York, 716 p.

DeJong, J. D., 1977 : Dutch tidal flats. Sedimentary Geology, 18, 13-23.

Eisma, D., 1981 : Supply and deposition of suspended matter in the North Sea. In Nio, S. D., Shuttenhelm, R. T.E. and Van Weering, T.C.E., eds., Holocene Marine Sedimentation in the North Sea Basin, International Association of Sedimentologists Special Publication, no. 5, 415-428.

Elliott, T., 1986 : Siliciclastic shorelines. In Reading, H. E., ed., Sedimentary Environments and Facies, Blackwell Science, Oxford, 155-188.

Evans, G., 1965 : Intertidal flat sediments and their environments of deposition in the Wash. Quarterly Journal of Geological Society of London, 121, 209-241.

Evans, G., 1975 : Intertidal flat deposits of the Wash, western margin of the North Sea. In Ginsburg, R. N., ed., Tidal Deposits: A Casebook of Recent Examples and Fossil Counterparts, Springer-Verlag, New York, 13-20.

Fan, D. and Li, C., 2002 : Rhythmic deposition on mudflats in the mesotidal Changjiang Estuary, China. Journal of Sedimentary Research, 72, 543-551.

Feng, H. and Wang, Z., 1986 : Holocene sea-level changes and coastline shifts in Zhejiang province. Department of Geography, Hangzhou University, $23 \mathrm{p}$.

Frey, R. W., Dorjes, J. and Howard, J.D., 1989 : Coastal sediments and patterns of bioturbation, eastern Buzzards Bay, Massachusetts. Journal of Sedimentary Petrology, 59, 1022-1035.

Harris, P.T., Heap, A.D., Bryce, S. M., Porter-Smith, R., Ryan, D. A. and Heggie, D. T., 2002 : Classification of Australian clastic coastal depositional environments based upon a quantitative analysis of wave, tidal, and river power. Journal of Sedimentary Research, 72, 858-870.

Hayes, M. O., 1979 : Barrier island morphology as a function of tidal and wave regime. In Leatherman, S.P., ed., Barrier Islands, Academic Press, New York, 1-27.

Kim, Y.H., 1997 : Holocene transgressive stratigraphy of macrotidal flat in the southeastern Yellow Sea: Gomso Bay, Korea. Unpub1. MSc. Thesis, Seoul National University,
Seoul, 101 p.

Kim, Y.H., Lee, H.J., Chun, S. S., Han, S. J. and Chough, S. K., 1999 : Holocene transgressive stratigraphy of a macrotidal flat in the southwestern Yellow Sea: Gomso Bay, Korea. Journal of Sedimentary Research, 69, 328-337.

Klein, G.D., 1971 : A sedimentary model for determining paleotidal range. Geological Society of America Bulletin, 82, 2582-2592.

Klein, G.D., 1977 : Clastic tidal facies. Continuing Education Publication Company, Illinois, 149 p.

Klein, G. D., 1985 : Intertidal flats and intertidal sandbodies. In Davis, R.A. Jr., ed., Coastal Sedimentary Environments, Springer-Verlag, New York, 187-224.

Knight, R.J. and Dalrymple, R.W., 1975 : Intertidal sediments from the south shore of Cobequid Bay, Bay of Fundy, Nova Scotia, Canada. In Ginsburg, R. N., ed., Tidal Deposits : A Casebook of Recent Examples and Fossil Counterparts, Springer-Verlag, New York, 47-56.

Korea Meteorological Administration, 1997 : Automatic Weather Station Data. Annual Report, 09200-73320-2613, $698 \mathrm{p}$.

Korea Meteorological Administration, 1998: Automatic Weather Station Data. Annual Report, 09200-73320-2613, $724 \mathrm{p}$.

Korea Ocean Research and Development Institute, 1991 : A study on the intertidal zone environment of west and south coasts of Korea (III). Korea Ocean Research and Development Institute, Seoul, Korea, Report, BSPG 00124395-5, $162 \mathrm{p}$.

Korea Ocean Research and Development Institute, 1994: Quaternary sea-level changes and their implication in the evolution of coastal depositional environments (III). Korea Ocean Research and Development Institute, Seoul, Korea, Report, BSPG 00223-732-5, 315 p.

Krögel, F. and Flemming, B. W., 1998, Evidence for temperature-adjusted sediment distributions in the back-barrier tidal flats of the East Frisian Wadden Sea (Southern North Sea). In Alexander, C.R., Davies, R.A. and Henry, V.J., eds., Tidalites : processes and products, SEPM Special Publication, no. 61, 31-41.

Larsonneur, C., 1994 : The Bay of Mont-Saint-Michel : A sedimentation model in a temperate macrotidal environment. Senckenbergiana Maritima, 24, 3-63.

Lee, H. J., Chun, S. S., Chang, J.H. and Han, S. J., 1994 : Landward migration of isolated shelly sand ridge (chenier) on the macrotidal flat of Gomso Bay, west coast of Korea : Controls of storms and typhoon. Journal of Sedimentary Research, A64, 886-893.

Li, C., Wang, P., Daidu, F., Bing, D. and Tiesong, L., 2000 : Open-coast intertidal deposits and the preservation potential of individual laminae: a case study from eastcentral China. Sedimentology, 47, 1039-1051. 
Masselink, G. and Short, A.D., 1993 : The effect of tide range on beach morphodynamics and morphology : a conceptual beach model. Journal of Coastal Research, 9, 785-800.

McCave, I.N., 1970 : Deposition of fine grained suspended sediment from tidal currents. Journal of Geophysical Research, 75, 4151-4159.

Middleton, G.V., 1991 : A short historical review of clastic tidal sedimentology. In Smith, D. G., Reinson, G. E., Zaitlin, B. A. and Rahmani, R. A., eds., Clastic Tidal Sedimentology, Canadian Society of Petroleum Geologists Memoir, no. 16, ix-xv.

Mukherjee, K. K., Das, S. and Chakrabarti, A., 1987 : Common physical sedimentary structure in a beach-related opensea siliciclastic tropical tidal flat at Chandipur, Orissa, India and Evaluation of the Weather conditions through discriminant analysis. Senckenbergiana Maritima, 19, 261-293.

National Fisheries Research and Development Institute, 1997 : Oceanographic observations. Annual Report, no. $46,545 \mathrm{p}$.

National Fisheries Research and Development Institute, 1998 : Oceanographic observations. Annual Report, no/ 47, 327 p.

Pirazzoli, P.A., 1991 : World atlas of Holocene sea-level changes. Elsevier, Amsterdam, 300 p.

Posamentier, H.W. and Allen, G.P., 1993 : Variability of the sequence stratigraphic model : Effects of local basin factors. Sedimentary Geology, 86, 91-109.

Posamentier, H. W., Jervy, M. T. and Vail, P. R., 1988 : Eustatic controls on clastic deposition I-conceptual framework. In Wilgus, C. K., Hastings, B. S., Kendall, C. G. S. C., Posamentier, H.W., Ross, C.A. and Van Wagoner, J.C., eds., SeaLevel Changes: An Integrated Approach. SEPM Special Publication, no. 42, 109-124.

Reineck, H.E., 1963 : Sedimentgefuge im Bereich der sudichen Nordsee. Abh. Senckenb. Naturforsch. Ges., 503 p.

Reineck, H.E., 1969 : Zwei Sparkerprofile sudostlich Helgoland. Natur. Mus. Frankf., 99, 9-14.

Reineck, H.E., 1972 : Tidal flats. In Rigby, J.K. and Hamblin, W.K., eds., Recognition of Ancient Sedimentary Environments, SEPM Special Publication, no. 16, 146-159.

Reineck, H.E., 1975 : German North Sea tidal flats. In Ginsburg, R.N., ed., Tidal Deposits: A Casebook of Recent Examples and Fossil Counterparts, Springer-Verlag, New York, 5-12.

Reineck, H. E. and Cheng, Y. M., 1978 : Sedimentologische und faunistische untersuchungen an Watten in Taiwan. I. Aktuogeologische untersuchungen. Senckenbergiana Marit., 10, 85-115.

Reineck, H. E. and Singh, I. B., 1980 : Depositional Sedimentary Environments. 2nd ed. Springer-Verlag, New York, 430 p. Schlager, W., 1993 : Accommodation and supply- a dual con- trol on stratigraphic sequence. Sedimentary Geology, $\mathbf{8 6}$, 111-136.

Scott, D. B. and Greenberg, D. A., 1983 : Relative sea-level rise and tidal development in the Fundy tidal system. Canadian Journal of Earth Sciences, 20, 1554-1564.

Short, A. D., 1991 : Macro-meso tidal beach morphodynamics an overview. Journal of Coastal Research, 7, 417-43.

Thompson, R. W., 1968 : Tidal flat sedimentation on the Colorado River Delta, northwestern Gulf of California. Geological Society of America Memoir, no. 107, 413 p.

Thompson, R. W., 1975 : Tidal-flat sediments of the Colorado River Delta, northwestern Gulf of California. In Ginsburg, R.N., ed., Tidal Deposits : A Casebook of Recent Examples and Fossil Counterparts. Springer-Verlag, New York, 57-66.

Van de Plassche, O. and Roep, T.B., 1989 : Sea-level changes in the Netherlands during the last 6,500 years: Basal peat vs. coastal barrier data. In Scott, D. B., Pirazzoli, P. A. and Honig, C. A., eds., Late Quaternary Sea-Level Correlation and Applications, Elsevier, Amsterdam, 41-56.

Van der Spek, A.J.F. and Beets, D.J., 1992 : Mid-Holocene evolution of a tidal basin in the western Netherlands : A model for future changes in the northern Netherlands under conditions of accelerated sea-level rise. Sedimentary Geology, 80, 185-197.

Van Wagoner, J.C., Mitchum, R. M., Campion, K. M. and Rahmanian, V.D., 1990 : Siliciclastic sequence stratigraphy in well logs, cores, and outcrops. American Association of Petroleum Geologists Methods in Exploration Series, no. 7, 55 p.

Walker, R.G. and Plint, A.G., 1992 : Wave- and stormdominated shallow marine systems. In Walker, R. G. and James, N.P., eds., Facies Models : Response to Sea-Level Change, Geological Association of Canada, 219-238.

Weimer, R.J., Howard, J.D. and Lindsay, D.R., 1982 : Tidal flats and associated tidal channel. In Scholle, P. A. and Spearing, D., eds., Sandstone Depositional Environments, American Association of Petroleum Geologists Memoir no. $31,191-245$

Wells, J.T., 1983 : Dynamics of coastal fluid muds in low-, moderate-, and high-tide-range environments. Can. J. Fish. Aquat. Sci., 40, 130-142.

Woodroffe, C.D., Curtis, R.J. and McLean, R.F., 1983 : Development of a chenier plain, firth of Thames, New Zealand. Marine Geology, 53, 1-22.

Wright, L.D. and Short, A. D., 1984 : Morphodynamic variablility of surf zones and beaches: a synthesis. Marine Geology, 56, 339-364.

Yang, B. C., 2000 : Seasonal cycle of surface sediment distribution and evolution of sedimentary facies on the Baeksu intertidal flat, southwestern open coast of the Korean Peninsula. Unpubl. MSc. Thesis, Chonnam National Univer- 
sity, $147 \mathrm{p}$.

Yang, B.C. and Chun, S.S., 2000 : New sedimentological meanings of mud balls in the Baeksu intertidal flat, southwestern coast of Korea. Tidalite 2000, 5th International Conference on Tidal Environments, Seoul, Jun. 1217, (Proceedings), 165-169.

Yang, B. C. and Chun, S. S., 2001 : A seasonal model of surface sedimentation on the Baeksu open-coast intertidal flat, southwestern coast of Korea. Geosci. J., 5, 251-262.

Yang, H. and Xie, Z., 1984 a : Sea-level changes in East China over the past 20,000 years. In Whyte, R. O., ed., The Evolution of Eastern Asian Environment, University of Hong Kong, 288-308.

Yang, H. and Xie, Z., 1984 b : A perspective on sea-level fluctuations and climatic variations. Acta Geologica Sinica, 39, 20-39.

Yeo, R. K. and Risk, M.J., 1981 : The sedimentology, stratigraphy, and preservation of intertidal deposits in the Minas Basin System, Bay of Fundy. Journal of Sedimentary Petrology, 51, 245-260. 